\title{
Sultan Hamengku Buwono IX: Manuver Stabilisasi dan Rehabilitasi Perekonomian Indonesia awal Orde Baru
}

\section{Sultan Hamengku Buwono IX: Maneuver for Stabilization and Rehabilitation of the Indonesian Economy at the beginning of the New Order Era}

\author{
Rizal Zamzami ${ }^{1}$ \\ 2Program Studi Sejarah Peradaban Islam, UIN Sayyid Ali Rahmatullah Tulungagug \\ email: rizalzamzami@iain-tulungagung.ac.id
}

\begin{tabular}{l} 
INFORMASI ARTIKEL \\
\hline Diterima: 25 September 2021 \\
Direvisi: 29 Desember 2021 \\
Publikasi Online: \\
31 Desember 2021 \\
KATA KUNCI
\end{tabular}

Sultan HB IX, Manuver Stabilisasi, Rehabilitasi Perekonomian

\begin{abstract}
The purpose of this paper is to describe the strategic steps for completing the stabilization and rehabilitation of the early New Order economy. The method used is a qualitative method using a historical approach and economic theory to examine the economic maneuvers of Sultan HB IX. The research method used is a historical research method in which there are 5 stages: topic selection, heuristics, source criticism, interpretation, and historiography. The result of this research is that after Sultan HB IX occupied strategic positions, namely Waperdam Ekubang, Menutama EKKU, and Minister of EKUIN in the government. Sultan HB IX issued his politicaleconomic statement which also became a maneuver to solve problems in the economic field. From the results of these studies, it can be concluded that the solution to economic problems at the beginning of the new order was by taking actions at home and abroad which would provide a positive stimulus for the Indonesian economy.
\end{abstract}

\section{A B S T R A K \\ Tujuan penulisan ini untuk mendeskripsikan langkah-langkah strategis penyelesaian stabilisasi dan rehabilitasi ekonomi awal pemerintahan Orde Baru. Metode yang digunakan ialah metode kualitiatif dengan menggunakan pendekatan sejarah dan teori ekonomi untuk menelaah manuver ekonomi Sultan HB IX. Metode penelitian yang digunakan adalah metode penelitian sejarah dimana ada 5 tahap diataranya: pemilihan topih, heruistik, kritik sumber, interprestasi, dan historiografi. Hasil dari penelitian ini adalah Setelah Sultan HB IX menduduki jabatan yang strategis yaitu Waperdam Ekubang,Menutama EKKU, dan Meneg EKUIN dalam pemerintahan. Sultan HB IX mengeluarkan pernyataan politik ekonominya yang sekaligus menjadi manuver untuk menyelesaikan persoalan}

Heritage: Journal of Social Studies | Vol 2, No 2, Desenber 2021 
dalam bidang ekonomi. Dari hasil penelitian tersebut dapat disimpulkan bahwa Penyelesaiannya masalah ekonomi di awal orde baru yaitu dengan cara dilakukan pengambilan tindakan di dalam negeri maupun di luar negeri yang nantinya memberikan angin segar bagi perekonomian Indonesia.

(C) Heritage: Journal of Social Studies Institut Agama Islam Negeri Jember, Indonesia https://doi.org/ 10.xxxx/ xxxx

This is an open access article under the CC-BY-SA license

\section{Pendahuluan}

Sultan Hamengku Buwono IX adalah Raja Kesultanan Yogyakarta yang memimpin Kesultanan Yogyakarta pada tiga masa yaitu mulai diangkat menjadi sultan pada masa Kolonial Belanda 1940, masa pendudukan Jepang 1942 dan masa kemerdekaan Republik Indonesia 1945. Sultan Hamengku Buwono IX yang bernama kecil GRM Dorodjatun merupakan putra pasangan GPH Purboyo dan RA Kustilah. Beliau sejak kecil memperoleh pendidikan dan telah terbiasa tinggal dengan keluarga Belanda guna mempelajari karakter, budaya dan watak orang Belanda yang diharapkan oleh ayahnya Sultan Hamengku Buwono VIII agar dapat digunakan untuk menghadapi orang Belanda. Sultan Hamengkubuwono IX selaku pemimpin D.I. Yogyakarta sangat berperan penting dalam mempertahankan kemerdekaan Indonesia baik pada saat Agresi Militer Belanda I dan Agresi Militer Belanda II. Sultan Hamengku Buwono IX sangat berperan dalam memperjuangkan kemerdekaan Republik Indonesia mulai dari pasca Proklamasi Kemerdekaan Indonesia, pembentukan Pemerintahan Republik Indonesia, masa Agresi Militer Belanda I maupun II sampai pada saat penyerahan dan pengakuan resmi kedaulatan Indonesia oleh Kerajaan Belanda. Sultan Hamengku Buwono IX sangat berperan dalam memperjuangkan kemerdekaan Republik Indonesia mulai dari pasca Proklamasi Kemerdekaan Indonesia, pembentukan Pemerintahan Republik Indonesia, masa Agresi Militer Belanda I maupun II sampai pada saat penyerahan dan pengakuan resmi kedaulatan Indonesia oleh Kerajaan Belanda. Peranperan Sultan Hamengku Buwono IX tersebut antara lain yaitu (1).Sultan Hamengku Buwono IX menyatakan bahwa Kesultanan Yogyakarta berada di dalam naungan NKRI sesaat setelah Proklamasi Kemerdekaan RI, hal ini menimbulkan semangat perjuangan dan rasa optimis dari kalangan rakyat dan pemimpin bangsa dalam mempertahankan kemerdekaan RI. (2). Pada masa Agresi Militer Belanda I, saat Ibu Kota RI di Jakarta tidak lagi aman untuk menjalankan roda pemerintahan, maka Sultan Hamengku Buwono IX menyediakan Yogyakarta sebagai Ibu Kota Republik Indonesia pada tahun 1946.(3). Sultan Hamengku Buwono IX banyak menyumbangkan bantuan moril dan materil untuk keperluan jalannya roda pemerintahan seperti bantuan kepada para pegawai negeri dan para pejuang dalam mempertahankan kemerdekaan RI. (4). Sultan Hamengku Buwono IX berperan sebagai 
inisiator dalam Serangan Umum 1 Maret 1949. (5). Sultan Hamengku Buwono IX adalah sosok pemimpin yang diakui kredibilitasnya dalam diplomasi dan penghubung antara Pemerintah RI dan Kerajaan Belanda pada saat pengakuan kedaulatan Indonesia oleh Belanda 1949.

Menurut Mas'oed Mohtar (1989), Selain persoalan defisit anggaran, hiperinflasi, dan terkurasnya cadangan devisa. negara juga masih menanggung hutang luar negeri. Pada masa Demokrasi Terpimpin menciptakan hutang luar negeri yang berjumlah $\$ 2.358$ juta. Hampir 42 persen kepada Uni Soviet, hampir 10 persen kepada Jepang, dan 7.5 persen kepada Amerika Serikat. Pembayaran hutang luar negeri tersebut dijadwalkan selama tujuh tahun mulai 1966. Ditambah lagi, menurut White et al. (2016), pemerintah harus membayar konpensasi untuk perusahaan-perusahaan asing yang dinasionalisasikan. Akhirnya pemerintah harus membayar kembali \$ 530 juta hutang luar negerinya yang jatuh tempo pada tahun 1966. Pada 1965, Indonesia juga tidak mampu memenuhi kewajiban hutang luar negeri. Bank Indonesia sebagai bank sentral, tidak mampu membayar tunai surat-surat hutang dan harus menunda pembayaran sejumlah hutang perdagangan luar negeri.

Kondisi perekonomian yang lumpuh harus segera diselesaikan supaya krisis tidak terjadi, penerapan stabilisasi ekonomi dan politik menjadi pilihan utama bagi pemerintahan awal Orde Baru sebagai langkah strategis untuk memecahkan permasalahan bangsa ini. Muncullah tiga serangkai yaitu Suharto sebagai pemegang kekuasaan tertinggi bidang eksekutif kenegaraan, Sultan HB IX yang diberi kepercayaan untuk memecahkan masalah rehabilitasi dan stabilisasi perekonomian Indonesia, dan Adam Malik yang ditugaskan untuk memulihkan kepercayaan Internasional bahwa Indonesia tidak akan menjadi instabilitas di kawasan negara-negara Asia Tenggara.

\section{Tinjauan literatur}

\section{Sekilas Tentang Sultan HB IX}

Menurut Roem et al. (1982), Sultan HB IX lahir pada 12 April 1912 M di Kampung Sompilan, J1. Ngasem No.13, Yogyakarta. Nama kecilnya ialah Dorodjatun. Ia merupakan putra dari Gusti Pangeran Haryo Purboyo dan R.A. Kustilah. Pada waktunya, ia diangkat menjadi Pangeran Adipati Anom Hamengku Negara Sudibya Raja Putra Narendra ing Mataram dan dinobatkan menjadi Sampeyan Dalem Ingkang Sinuwun Kanjeng Sultan Hamengku Buwono Senopati Ingalaga Ngabdurrakhman Sayidin Panatagama Kalifatullah Kaping-IX. Gelar tersebut memiliki arti bahwa Sultan adalah Penguasa di dunia, dan juga Senopati Ing Ngalaga yang memiliki arti bahwa sultan mempunyai kekuasaan dalam menentukan perdamaian atau peperangan dan panglima angkatan perang pada saat terjadi peperangan. Di samping itu sultan adalah Abdurrahman Sayidin Panatagama yang berarti penata agama sebab sultan diakui sebagai kalifatullah yang menjadi 
pengganti Nabi Muhammad SAW. Dengan demikian Menurut Darban et al. (1998), Sultan HB IX memiliki anugerah dari Tuhan untuk memegang kerajaan dan memiliki kekuasaan militer, politik, dan agama yang absolut.

Pendidikan formal Sultan HB IX dilakukan di sekolah milik Belanda dan selama menempuh pendidikannya ia selalu dititipkan ke keluarga Belanda oleh ayahnya Sultan HB VIII dengan alasan supaya putra-putranya bersikap terbuka terhadap pembaharuan akan tetapi tetap menjaga kepribadian sebagai orang Jawa. Setelah menyelesaikan pendidikan formal di negaranya, Ia melanjutkan pendidikannya ke negeri Belanda di kota Leiden dengan jurusan yang diambilnya ialah Indologi. Sebelum pendidikannya selesai di negeri Belanda, ia diminta kembali oleh ayahnya untuk pulang dikarenakan situasi dunia yang memburuk akibat perang Dunia II dan kesehatan Sultan Hamengku Buwono VIII yang semakin memburuk. Setelah Sultan HB VIII meninggal, Dorodjatun menggantikan posisinya sebagai sultan berikutnya dan baru pada 18 Maret 1940 ia resmi dinobatkan sebagai Sultan Yogyakarta dengan gelar Sampeyan Dalem Ingkang Sinuwun Kandjeng Sultan Hamengku Buwono Senopati Ing Ngalaga Ngabdurrahman Sayidin Panatagama Kalifatullah Kaping IX.

Dalam kiprahnya sebagai Sultan HB IX yang dimulai dari masa pendudukan Belanda, pendudukan Jepang sampai dengan kemerdekaan RI. Pada 5 September 1945, Sultan HB IX mengeluarkan amanat yang menyatakan bahwa Kesultanan Yogyakarta melebur dalam suatu kesatuan dengan RI. Setelah meleburnya Yogyakarta sebagai bagian dari Republik Indonesia, Sultan HB IX mulai mengambil peran dan mempunyai posisi strategis dalam pemerintahan Indonesia. Pada pemerintahan awal pemerintahan Orde Baru, Sultan HB IX diberikan kepercayaan dan amanat untuk menyesaikan permasalahan ekonomi akibat krisis ekonomi Indonesia.

Menurut Inventaris Arsip Menteri Negara Bidang Keuangan dan Industri (2011), Sultan HB IX dalam Kabinet Ampera I, memangku jabatan sebagai Menteri utama Bidang Ekonomi dan Keuangan dan menjabat juga sebagai Raja Kesultanan Yogyakarta ke-9. Pada kabinet Ampera II, kementerian ini diubah namanya menjadi Menteri Negara Ekonomi, Keuangan dan Industri (Meneg EKUIN) berdasarkan Keputusan Presiden No. 171 tahun 1967. Dalam kabinet ini Sultan HB IX masih dberikan kepercayaan untuk menduduki jabatan tersebut. Pada kabinet pembangunan yang merupakan awal era Orde Baru, kementerian ini diubah menjadi Menteri Negara Ekonomi, Keuangan, dan Industri (Meneg EKUIN). Sultan HB IX Masih menduduki jabatan tersebut.

Menurut Darban et al. (1998), Munculnya Sultan HB IX sebagai figur pemimpin yang penting di negaranya pada masa krisis. Di bawah petunjuknya dan dengan nasihat dari para ahli ekonomi di sekelilingnya, rakyat bisa mengharapkan perbaikan dalam 
kehidupan sehari-hari mereka. Progam ekonominya, termasuk beberapa pembalikan tajam dari kebijakan sebelumnya, seperti sebuah blue print untuk pemulihan ekonomi Indonesia, khususnya persoalan keuangan negara yang dimanfaatkan untuk membiayai kelangsungan kerja birokrasi pemerintah (birokrasi sipil, birokrasi militer, serta perusahaan-perusahaan negara), membiayai proyek-proyek pembangunan nasional untuk memajukan kehidupan masyarakat terutama di bidang insfrastruktur, dan sektor-sektor kehidupan yang dinilai strategis untuk kemajuan dan kesejahteraan masyarakat luas.

\section{Metode}

Metode yang dipakai metode penelitian sejarah. Menurut Kuntowijoyo metode penelitian sejarah ialah pelaksanaan petunjuk teknis tentang bahan, kritik, interpretasi, dan penyajian sejarah. Metode penelitian sejarah yang digunakan dalam penelitian ini terdapat empat tahap yang bertujuan untuk merekonstruksi kesejarahan. Menurut Kuntowijoyo (2003), Kuntowijoyo menjelaskan lima tahap penelitian sejarah itu sebagai berikut :

1. Pemilihan Topik

Topik dalam sebuah penelitian dipilih berdasarkan tingkat ketertarikan peneliti terhadap tema yang akan disusun berkaitan dengan tema yang dikaji. Dengan memperhatikan hal ini, peneliti akan lebih mudah merumuskan masalah penelitian yang akan dikaji. Mengingat alasan inilah peneliti memilih topik Sultan Hamengku Buwono IX: Manuver Stabilisasi dan Rehabilitasi Perekonomian Indonesia awal Orde Baru.

2. Heuristik (Pengumpulan Sumber)

Setelah menentukan tema atau topik penelitian, maka tahap selanjutnya adalah mengumpulkan sumber-sumber sejarah yang relevan dengan tema penelitian atau yang dikenal dengan istilah heuristik. Istilah "heuristik" berasal dari kata "heuriskien" yang dalam bahasa Yunani berarti "menemukan." Dalam konteks penulisan sejarah, heuristik biasanya diartikan sebagai kegiatan sejarawan untuk mengumpulkan sumber-sumber sejarah. Dalam Penelitian yang berjudul "Sultan Hamengku Buwono IX: Manuver Stabilisasi dan Rehabilitasi Perekonomian Indonesia awal Orde Baru" peneliti mengumpulkan berbagai sumber sejarah yang relevan dengan tema penelitian berupa buku, jurnal, koran, dan sumber internet.

3. Kritik Sumber (Verifikasi)

Langkah selanjutnya setelah memperoleh sumber-sumber penulisan sejarah yang dibutuhkan dalam penelitian ialah verifikasi keabsahan sumber sejarah atau kritik sejarah. Kritik sumber merupakan usaha mengolah dan menyaring 
sumber-sumber yang telah dikumpulkan. Melalui upaya verifikasi data, peneliti memilih dan memilah data-data yang sungguh-sungguh relevan dengan penelitian ini untuk kemudian dijadikan sumber data untuk mendukung penelitian ini, sedangkan data lain yang kurang relevan tidak digunakan sebagai sumber.

Menurut Widja (1989), kritik sumber dapat dibedakan menjadi dua jenis, yaitu, kritik ekstern dan intern. Kritik ekstern berkaitan dengan autensitas atau keaslian sumber sejarah. Kritik ini bertujuan untuk menganalisis apakah sumber- sumber yang diperoleh merupakan sumber asli atau hanya sumber turunan. Kritik ekstern juga berupaya meneliti utuh atau tidaknya sumber-sumber yang diperoleh. Kritik ekstern pada umumnya meneliti sumber-sumber sejarah berdasarkan gaya tulisan, bahasa, warna kertas, serta bentuk dan jenis kertas dokumen, arsip, dan sebagainya yang dijadikan sumber sejarah.

Sedangkan kritik intern berkaitan dengan kredibilitas sumber sejarah. Kritik jenis ini dilakukan untuk memastikan bahwa sumber diperoleh memang merupakan sumber yang dicari. Kritik intern dilakukan untuk membuktikan bahwa kesaksian yang diberikan suatu sumber dapat dipercaya. Kritik intern dapat ditempuh dengan mengadakan penelitian intrinsik terhadap sumber-sumber yang didapatkan dan membandingkan data dari berbagai sumber.

4. Interpretasi

Menurut Pranoto (2001), Interpretasi adalah cara penulis menetapkan makna dan keterkaitan atau hubungan antara fakta-fakta yang telah berhasil dihimpun oleh penulis. Interpretasi perlu dilakukan dalam analisis sumber data sejarah untuk mengurangi unsur subjektifitas dalam kajian sejarah. Suatu objek sejarah dapat dipelajari secara objektif bila objek tersebut memiliki eksistensi yang merdeka di luar pikiran manusia agar memperoleh pengetahuan yang tidak memihak dan benar.

5. Historiografi

Historiografi merupakan cara penulisan, pemaparan, atau pelaporan hasil penelitian sejarah yang telah dilakukan. Ini adalah teknik akhir dari penelitian sejarah, di mana penulisan dari hasil penelitian ini dituangkan ke dalam laporan penelitian. Historiografi adalah usaha untuk menuliskan peristiwa secara kronologis, logis, dan sistematis dengan menerangkan fakta-fakta sejarah yang diperoleh sehingga akan dihasilkan suatu kisah yang ilmiah. Hasil dari historiografi ini adalah jurnal dengan judul Sultan Hamengku Buwono IX: Manuver Stabilisasi dan Rehabilitasi Perekonomian Indonesia awal Orde Baru. 


\section{Hasil \& Diskusi \\ Penstabilan Ekonomi Sultan HB IX}

Permasalahan inflasi yang melambung tinggi, pemerintah Orba memerlukan berbagai kebijaksanaan di bidang ekonomi untuk menurunkannya. Dalam hal ini pemerintah pun mulai berusaha merealisasikan berbagai kebijaksanaan yang sudah dituangkan dalam progam stabilisasi, konsolidasi, dan rehabilitasi. Kebijakan ekonomi yang dilakukan pemerintah tersebut didasarkan pada hasil ketetapan MPRS No. XXIII 5 Juli 1966 mengenai "Pembaharuan Kebijaksanaan Landasan Ekonomi Keuangan dan Pembangunan". Ketetapan MPRS tersebut sebagian besar merupakan hasil rekomendasi dari seminar "Masalah Ekonomi dan Keuangan" yang diselenggarakan oleh Cabang KAMI di Fakultas Ekonomi Universitas Indonesia.

Menurut Baskoro \& Sunaryo (2011), Sultan HB IX muncul sebagai aktor yang berpengaruh dalam penstabilan ekonomi Indonesia. Sesudah Supersemar, terjadi perombakan kabinet dan Sultan HB IX diangkat menjadi Wakil Perdana Menteri Ekonomi, Keuangan, dan Pembangunan (Waperdam Ekubang). Kabinet ini berusia hanya empat bulan, karena setelah 5 Juli 1966 terjadi perombakan kabinet yang memfokuskan perhatian dari politik ke bidang ekonomi dan peranan sultan HB IX semakin terlihat karena Sultan HB IX ditunjuk menjadi Menutama Bidang Ekonomi dan Keuangan dalam Kabinet Ampera I. Kabinet Ampera dibentuk pada 25 Juli 1966 dan berakhir pada 17 Oktober 1967.

Sultan HB IX sebagai Waperdam Ekubang dalam Kabinet Dwikora melakukan pertemuan yang pertama dengan Dewan Perwakilan Rakyat Gotong Royong (DPR-GR) yang diadakan pada 6 Mei 1966. Dalam pertemuan tersebut Sultan HB IX memberikan keterangan tentang keadaan ekonomi dan keuangan negara serta tentang rencana tindakantindakan yang dilakukan pemerintah dalam bidang Ekubang. Sebelum pertemuan tersebut, Sultan HB IX mengeluarkan statement tentang kebijakan pemerintah dalam bidang Ekubang diluar sidang DPR-GR. Hal ini dilakukan sultan karena statemen tersebut harus segara dilakukan untuk memberi landasan kerja kepada semua menteri dan deputi menteri beserta pejabat pemerintah lainnya dalam bidang Ekubang.

Statemen Sultan HB IX tentang garis-garis kebijaksanaan pemerintah dalam bidang Ekubang dilakukan sebanyak dua kali. Statemen pertama dilakukan pada 4 April 1966 dan yang kedua dilakukan pada 12 April 1966. Statemen yang pertama ditujukan khusus kepada luar negeri untuk menerangkan keadaan ekonomi yang terjadi di Indonesia dan keinginan untuk bekerja-sama dengan negara-negara lain dengan tujuan saling menguntungkan dan atas dasar hormat-menghormati dan saling percaya. 
Selanjutnya, Menurut Mas'oed Mohtar (1989), peryataan politik ekonomi yang kedua lewat Sultan Hamengku Buwono IX pada 12 April 1966. Pemerintah menyampaikan masalah-masalah yang dihadapi Indonesia sekaligus menggumumkan kebijaksanaankebijaksanaan untuk memecahkannya. Pertama, Indonesia mengahadapi masalah-masalah inflasi, defisit neraca pembayaran dan hutang luar negeri yang gawat. Apabila dibayarkan sesuai dengan penjadwalan, maka tidak aka ada lagi devisa yang tersisa untuk membiayai impor kebutuhan pokok. Kedua, rehabilitasi infrastruktur ekonomi akan ditekankan terutama melalui impor suku cadang. Ketiga, rasionalitas ekonomi akan menjadi dasar kebijaksanaan pemerintah dalam dan luar negeri.peryataan tersebut juga menunjukkan bahwa pemerintah akan menerima bantuan luar negeri tanpa syarat-syarat politik. Peryataan yang keempat, guna melibatkan daerah-daerah secara lebih aktif dalam proses pengambilan keputusan ekonomi, pemerintah pusat memberikan ijin pemerintah daerah untuk memanfaatkan sumber-sumber mereka untuk kepentingan sendiri asalkan tidak mematuhi pemerintah pusat. Kelima, subsidi pada perusahaan negara akan dihentikan. Keenam, penarikan pajak akan digalakkan melalui pembaharuan sistem pajak. Ketujuh, tindakan jangka pendek untuk stabilisasi dan rehabilitasi ekonomi akan diberi diambil. Untuk itu perusahaan-perusahaan swasta akan diberi kesempatan mengembangkan dan mengatur diri sendiri, akan tetapi pemerintah pusat akan tetap memberikan bimbingan seara umum.

Menurut Monfries (2018), dalam Stabilisasi dan rehabilitasi di bidang ekonomi dan keuangan, Sultan HB IX membutuhkan bantuan ahli ekonom untuk membantunya, mereka ialah Prof. Widjojo Nitisastro, Dr. Emil Salim, Prof. Ali Wardana, Prof. Mohamad Sadli, Prof. Sarbini, Johanes Sumarlin, Dr. Saleh Arif, dan Prof. Subroto. Terdapat pula segelintir ekonom yang dilatih oleh Belanda seperti Drs. Radius Prawiro dan Drs. Frans Seda, dan muncul juga tokoh ekonom Prof. Sumitro Joyoadikusumo yang muncul belakangan.

Sedayu et al. (2015), menyebutkan bahwa hasil pembentukan tersebut membuahkan hasil yang mana Sultan HB IX yang dibantu anggota tim inti ekonomi sultan berhasil mengembalikan Indonesia kembali menjadi anggota Bank Dunia dan IMF pada September 1966. Selain ke Amerika, sultan mengunjungi Jepang, Belanda, serta sejumlah negara Eropa. Kunjungan ke berbagai negara tersebut merupakan awal pembentukan IGGI, lembaga Koordinator pemberian pinjaman untuk Indoensia.

Selanjutnya, menurut Soedjatmoko (1997), tindakan yang diambil Sultan HB IX untuk penstabilan ekonomi ialah mengambil tindakan di dalam negeri maupun luar negeri. Pelaksanaan stabilisasi dalam bidang keuangan dalam negeri yaitu mengadakan progam penghematan pengeluaran uang negara di segala bidang, terutama pembiayaan proyekproyek yang secara ekonomi tidak menguntungkan; tidak mengeluarkan biaya besar- 
besaran untuk melakukan investasi atau penggantian alat-alat produksi, dan menerima pinjaman luar negeri sebesar 200 juta dolar AS untuk merehabilitasi alat-alat produksi yang sudah dipakai. Adanya program penghematan tersebut, semua perusahaan negara, baik komersial maupun bukan, harus beroperasi dengan norma ekonomi yang benar. Pemerintah pun juga harus meninjau kembali sistem perpajakannya dengan mengadopsi sistem pajak yang tidak hanya meningkatkan pendapatan, tetapi juga membimbing masyarakat menuju upaya ekonomi yang bermanfaat bagi dirinya dan juga negara.

Setelah situasi perekonomian dalam negeri menjadi jelas, strategi berikutnya ialah membuka kembali kerjasama dengan bantuan asing. langkah pertama yang dilakukan ialah terlebih dahulu memulihkan kembali kepercayaan dunia internasional dengan iktikad baik mampu memenuhi kewajibannya dalam bidang ekonomi dan keuangan. Untuk mewujudkannya, maka Indonesia perlu melakukan beberapa tindakan dengan bergabung kembali sebagai anggota di lembaga-lembaga ekonomi dan keuangan internasional seperti IMF dan Bank Dunia, menghubungi langsung para kreditor dengan maksud memberikan keterangan tentang keadaan ekonomi Indonesia yang sebenarnya sejak awal tahun 1966, dan berunding kepada pihak luar negeri untuk mengatur kembali pembayaran cicilan dan bunga hutang Indonesia. Sikap yang harus ditujukan ialah menghargai setiap bantuan yang lebih positif berupa kredit baru dengan prasyarat yang tidak melampaui kemampuan ekonomi Indonesia. Kerjasama yang dilakukan oleh Indonesia dengan bantuan asing berharap dapat memperoleh lebih banyak lagi keuntungan daripadanya, melalui pengaturan yang lebih sempurna dan penggunaan yang lebih baik. politik Indonesia yang menganut politik bebas-aktif, maka Indonesa akan menyambut baik bantuan ekonomi luar negeri tanpa ikatan politik dari semua negeri. Terlepas dari pro-kontra terkait kerjasama yang dilakukan dengan bantuan asing. Waktu itu perlu dilakukan mengingat kondisi perekonomian yang memburuk.

Sejarawan George McT Kahin menuliskan pertama Belanda menawarkan untuk mendirikan kembali satu daerah yang sama dengan kesultanan Mataram yang lama (sebelum dipecah). Meliputi Yogyakarta, Surakarta, Kedu, Banyumas, dan Madiun. Sultan akan menjadi wali negaranya. Kemudian daerah ini diperluas lagi dengan sisa bagian Jawa Tengah dan seluruh Jawa Timur termasuk Madura. Melihat Sultan tak tertarik, Belanda kemudian menambah tawarannya. Kali ini ditambah dengan sejumlah besar saham di perusahaan pelayaran Belanda dan perusahaan kereta api. "Sultan segera menolak tawaran ini, dan Belanda akhirnya terpaksa mengakui bahwa mereka telah salah menilai Sultan Hamengku Buwono IX," tulis Kahin. Sultan meneruskan perjuangannya untuk mengusir Belanda. Dialah yang sebenarnya punya ide mengobarkan serangan umum 1 Maret, 
bukan Soeharto. Serangan ini yang kemudian menjadi sorotan dunia dan menekan Belanda untuk mengakui kedaulatan Indonesia

\section{Kesimpulan}

Berdasarkan uraian di atas dapat disimpulkan bahwa permasalahan ekonomi awal Orde Baru merupakan permasalahan serius yang harus segera diselesaikan. Munculnya Sultan HB IX sebagai tokoh utama dalam stabilisasai dan rehabilitasi ekonomi beserta dengan para pakar ekonom terkemuka bergerak cepat untuk mengatasi permasalahan ekonomi tersebut. Setelah Sultan HB IX diberikan kepercayaan untuk pemulihan ekonomi, ia langsung mengeluarkan statement politik ekonominya sebanyak 2 kali. Statement pertama disampaikan mengenai ditujukan khusus kepada luar negeri untuk menerangkan keadaan ekonomi yang terjadi di Indonesia dan keinginan untuk bekerja-sama dengan negara-negara lain dengan tujuan saling menguntungkan satu sama yang lain. Statement yang kedua berkaitan tentang penyampaian masalah-masalah ekonomi yang dihadapi oleh Indonesia sekaligus mengumumkan kebijakan untuk menyelesaikannya.

Selanjutnya fokus yang dilakukan oleh Sultan HB IX ini mengambil tindakan di dalam negeri maupun luar negeri. Tindakan yang dilakukan diantaranya mengadakan progam penghematan pengeluaran uang negara di segala bidang, terutama pembiayaan proyekproyek yang secara ekonomi tidak menguntungkan, tidak mengeluarkan biaya besarbesaran untuk melakukan investasi atau penggantian alat-alat produksi, menerima pinjaman luar negeri dari Amerika SerIkat dan bergabung kembali sebagai anggota di lembaga-lembaga ekonomi dan keuangan internasional seperti IMF dan Bank Dunia.

\section{Referensi}

Baskoro, H., \& Sunaryo, S. (2011). Wasiat HB IX: Yogyakarta Kota Republik . Yogyakarta : Galang Press.

Darban, A. A., Sutijatiningsih, S., Nurcahyo, A. L., Setyawati, N., \& Nurdiyanto. (1998). Biografi Pahlawan Nasional Sultan Hamengku Buwana IX. Jakarta : Proyek Inventaris dan Dokumentasi Sejarah Nasional Direktorat Sejarah dan Nilai Tradisional Direktorat Jenderal Kebudayaan Departemen Pendidikan dan Kebudayaan.

Indonesia, A. N. R. (2011). Inventaris Arsip Menteri Negara Bidang Ekonomi, Keuangan, dan Industri Tahun 1967-1973.

Kuntowijoyo. (2003). Metodologi Sejarah. Yogyakarta : Tiara Wacana Yogya. Mas'oed Mohtar. (1989). Ekonomi dan Struktur Politik (Orde Baru 1966-1971) . Jakarta 
: Pustaka LP3ES.

Monfries, J. (2018). Keidupan Suktas Hamengku Buwono IX dari Yogyakarta. Yogyakarta : Biography.

Pranoto, W. S. (2001). Teori dan Metodologi Sejarah. Yogyakarta : Graha Ilmu .

Roem, M., Lubis, M., Mochtar, K., \& Maimoen, S. (1982). Takhta untuk rakyat: celahcelah kehidupan Sultan Hamengku Buwono IX - Google Buku. Jakarta : Gramedia Pustaka Utama.

Sedayu, A., Joko Suyono, S., Hidayat, D., \& Widiarsi, A. (2015). Hamengku Buwono IX Pengorbanan Sang Pembela Republik. Jakarta : Gramedia.

Soedjatmoko. (1997). A Political Format For Sustainable Development. The Politics of Economic Development in Indonesia: Contending Perspective, 194-197.

White, B., Henley, D., Pradadimara, D., Erwiza, E., Lindblad, T., Ossewijer, M., Tuerah, N., Boomgaard, P., Saptari, R., Nawiyanto, S., Suribidari, \& Wie, K. T. (2016). DARI KRISIS KE KRISIS: Masyarakat Indonesia Menghadapi Resesi Ekonomi Selama Abad ke-20. Yogyakarta : UGM Press.

Widja, I. G. (1989). Sejarah Lokal Suatu Perspektif dalam Pengajaran Sejarah. Jakarta : Departemen Pendidikan dan Kebudayaan Direktorat Jenderal Pendidikan Tinggi Proyek Pengembangan Lembaga Pendidikan Tenaga Kependidikan. 